\title{
Supply Chain Performance and Resilience of Japanese Firms
}

\author{
Yasutaka Kainuma \\ Department of Management Systems Engineering \\ Tokyo Metropolitan University, 6-6 Azumacho, Hino, Tokyo 191-0065, Japan \\ Email: kainuma@tmu.ac.jp
}

\begin{abstract}
This paper proposes a causal model of the SCM implementation method and SCM performance by referring to several research investigations. This study shows that there are factors similar to those derived through our proposed causal model and questionnaire survey. Their influences on SCM also revealed performance metrics. In particular, the improvement of the practice of business-critical matter factor, which includes the capability of inventory management and flexibility to customer demand, is efficient in improving SCM performance. As a result of the analysis, we identified the existence of an undisclosed factor related to the ambiguous interpretation of the definition of SCM. A few firms experienced a reduction in SCM performance and a deterioration of the index of ability of inventory management, the reduction of lead time, and the level of on-time delivery. The Great East Japan Earthquake was thought to have had an adverse effect on SCM performance, thereby highlighting the importance of creating supply chain resiliency.
\end{abstract}

Keywords: supply chain management, supply chain performance, supply chain resilience, structural equation modelling, Great East Japan Earthquake

\section{INTRODUCTION}

From the 1980's to the 1990's, Supply Chain Management (SCM) appeared to help companies adapt to competitive business environments and comply with unpredictable demands. The purpose of SCM is to improve not a single firm's performance, but instead the performances of a large number of companies that are engaged in similar products through collaboration, cooperation, and coordination amongst one another. Many research investigations have been conducted regarding SCM, but most of them were aimed at developing or improving technical approaches to SCM. Therefore, there are many theories and methods pertaining to SCM. However, it is not clear how companies utilize or apply implementation methods of SCM, or how SCM affects the companies' performance. Even the few studies addressing this usually only analyse a single firm or a small number of companies. Therefore, the relationship between SCM performance and the SCM implementation method needs to be more thoroughly examined. We evaluate the relationship between the SCM implementation method and SCM performance by applying questionnaire data to a hypothetic causal model in order to answer the following research questions:

Are there any differences in the SCM implementation method amongst companies?

How do the differences in SCM implementation methods affect SCM performance?

One of the key findings of this research is that there are undisclosed factors that are related to the interpretation of the definition of SCM.

\section{LITERATURE REVIEW}

Arashida et al. developed an SCM logistics score card (LSC) by investigating various kinds of score cards, and analyzed the relationship between a firm's supply chain performance and its managerial performance using real data provided by companies (Arashida et al., 2004). The SCM LSC was found to be an efficient tool for analyzing the relationship between a firm's supply chain performance and its managerial performance. The data were tested using factor analysis from which five factors were obtained: practical use of information technology, inventory control, SCM organization, correspondence with the market, and correspondence with the customers' demand. They also tested the data using regression analysis to resolve the relationship between the managerial index (e.g. inventory turnover, return on asset, and cash flow per one stock) and the aforementioned five factors. The results showed that when the factors' index increased, the managerial index became subordinate. Furthermore, they designed a hypothetic causal model that indicates how the performance driver factors (practical use of information technology and ability of SCM organization) militate each other and how they improve the managerial index through the operational factor (ability of inventory control). They tested the data using structural equation modelling and revealed that practical use of information technology itself does not directly affect managerial performance.

Cagliano (2004), Ragatz et al. (2005) and Yeung (2008) indicate there is need to develop independent criteria to measure supply chain performance because supply chain performance affects the ability to provide customer value.

Kim (2009) conducted questionnaire surveys to Korean and Japanese manufacturing firms in order to investigate how 
companies develop the framework for linking a firm's SC integration strategy to its competitive strategy, and to identify how such a linkage can be connected with improving organizational performance. To examine causal linkages within SCM practice, competition capability, the level of supply chain (SC) integration, and firm performance, questionnaire surveys were carried out to Korean and Japanese manufacturing firms. The results revealed that efficient SC integration may play a more critical role for sustainable SCM competitiveness in Korean firms, while the close interrelationship between the level of SCM practices and competition capability, which is based on SC integration, may have a more significant effect on SCM competitiveness in Japanese firms.

Table 1 Proposed measurement items

\begin{tabular}{|c|c|}
\hline Factor & Item \\
\hline SCM potential & $\begin{array}{l}\text { Accuracy of the interpretation of the SCM } \\
\text { definition } \\
\text { Expectation toward the introduction of SCM } \\
\text { Aggressiveness of reforming firms }\end{array}$ \\
\hline SCM strategy & $\begin{array}{l}\text { Practical use of information technology } \\
\text { Existence of proper efficiency rating system } \\
\text { Practical use of appropriate outsourcing }\end{array}$ \\
\hline $\begin{array}{l}\text { Organizational } \\
\text { cooperation }\end{array}$ & $\begin{array}{l}\text { Existence of joint goal setting } \\
\text { Practical information sharing } \\
\text { Width of related companies in supply chain } \\
\text { Existence of proper logistics network } \\
\text { Existence of simple SCM structure } \\
\text { Existence of appropriate commission }\end{array}$ \\
\hline $\begin{array}{l}\text { Business } \\
\text { accomplishment }\end{array}$ & $\begin{array}{l}\text { Capability of inventory management } \\
\text { Flexibility to customer demand } \\
\text { Practice of just-in-time method } \\
\text { Quality of product } \\
\text { Reduction of lead time } \\
\text { Increase of on-time delivery }\end{array}$ \\
\hline SCM Performance & $\begin{array}{l}\text { Improvement of return on asset } \\
\text { Increasing customer satisfaction level } \\
\text { Increasing repeat ratio }\end{array}$ \\
\hline
\end{tabular}

However, there is an important shortcoming of these research investigations. Arashida et al. measured the performance using financial indices instead of the effect of SCM implementation. Furthermore, both studies conducted by Arashida et al. and Kim failed to identify how interpretation of the SCM definition, which is vague, affects SCM performance with respect to SCM implementation method (Arashida et al., 2004; Kim S. W., 2009).

In small and medium enterprises (SMEs), Sukawari et al. indicates agile supply chain influence supply chain performance and agility is an important factor within the SMEs.

\section{HYPHOTHESIS DEVELOPMENT}

\subsection{The Element of Causals Model}

Figure 1 shows the SCM causal model developed in this study. The causal model proposes that the SCM potential will impact the SCM strategy, which will in turn impact business accomplishment both directly, and indirectly through the level of organizational cooperation, which impacts business accomplishment. Finally, organizational cooperation and business accomplishment impact SCM performance. The SCM potential can be divided into two subcategories, the SCM strategy can be divided into three subcategories, the organizational cooperation and business accomplishment can each be divided into six subcategories, and finally, the SCM performance can be divided into three subcategories. The subcategories included in each of the factors are shown in Table 1. As mentioned in the preceding section, the objective of this research is to evaluate the relationship between the SCM implementation method and SCM performance by applying questionnaire data to the hypothetic causal model. The following section describes the development of the proposal causal model and the construct variables.

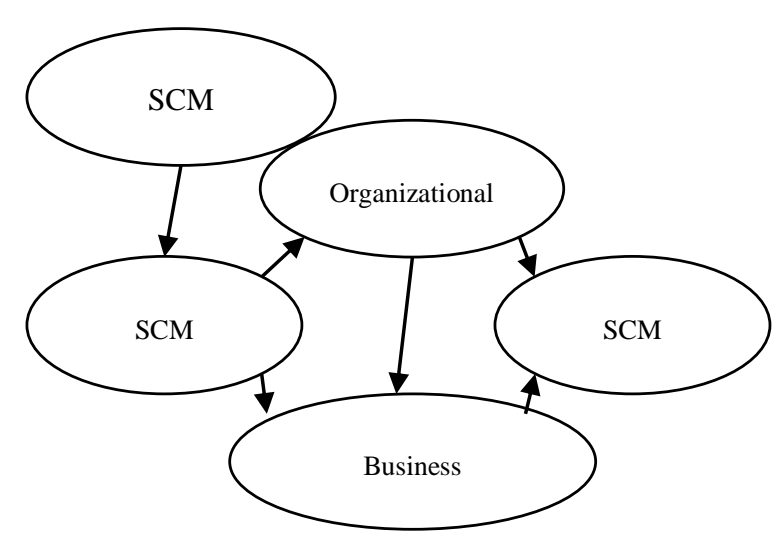

Figure 1 Proposal Casual Model

\subsubsection{The level of SCM Potential}

Regarding SCM potential, there are various potentials of SCM utilized, even though it has been approximately a decade since the implementation of SCM became popular. Furthermore, there have been very few studies that investigate how SCM potential affects SCM performance. However, there must be some effect of SCM potential on performance because differences in interpretation lead to different implementation methods. Therefore, in this study we investigate the effect of SCM potential on SCM performance.

\subsubsection{The level of SCM Strategy}

There are two types of SCM: SCM operation, and SCM strategy. It is important to implement SCM with practical use of information technology from the viewpoint of longevity. Mentzer et al. described the causal framework that shows that management philosophy affects SCM performance through SCM practice (Mentzer, J. T., 2001). Regarding SCM strategy, the existence of a proper efficiency rating system, and practical use of appropriate outsourcing are included, in addition to the strength of management leadership, existence of long-term aspects, and practical use of information technology. Regarding the existence of a proper efficiency rating system, it has been 
reported that even though it is important in evaluating worker activity, past measurement indices did not value activities related to SC performance, but instead valued individual business activity (Bowersox, D. J. et al., 2004; Goldratt, E. M., et al., 2001). Therefore, this study investigates the effects of the existence of a proper efficiency rating system as a subcategory of SCM strategy. Regarding practical use of appropriate outsourcing, it has been reported that even though outsourcing is useful for improving competitive advantage, excessive outsourcing risks losing core competence. Therefore, this study investigates the effect of appropriate outsourcing as a subcategory of SCM strategy.

\subsubsection{The level of Organizational Cooperation}

Until recently, it was not sufficient for companies to implement SCM across several companies. Therefore, it is necessary to promote the utilization of information technology not only to share information, but also incorporate the following: collaborative planning, forecasting, and replenishment (CPFR), which is used to automate and improve sales forecasting and replenishment amongst trading partners, thereby enabling participants to share improvements in inventory costs and revenue, as well as customer service (Browning B. and White A., 2000). Kim identified the linkage between SCM practice, competition capability, amount of SC integration, and firm performance in Japanese and Korean manufacturing firms. In particular, it was reported that SCM practice based on SC integration leads to SCM competitiveness in Japanese firms. Several studies have noted that merely implementing information technology is not sufficient, and requires practical use in order to be effective. In particular, Arashida et al. indicated that implementation of information technology does not directly affect financial performance, but instead indirectly affects it together with SCM organization through inventory management. Therefore, in this investigation, we propose that the SCM strategy does not have direct effect, but instead an indirect effect on SCM performance.

\subsubsection{Capability of Business Accomplishment}

The capability of business accomplishment has a direct effect on SCM performance. Arashida et al. indicated that the inventory management specifically affects SCM performance. Suzuki et al. (2009) verified that flexibility to customer demand is relevant to financial performance. Goldratt (2009) also explained the importance of corresponding with the market demand. The just-in-time method has supported Toyota's financial performance as a main method of Toyota's production system. Based on the aforementioned, the subcategories of business accomplishment include inventory management, flexibility to customer demand, and use of the just-in-time method.

\subsubsection{SCM Performance}

As a performance index of the Supply Chain Council \& Supply Chain Operation Reference (SCOR) model, reliability, responsiveness, agility, cost, and asset are determined. The SCOR model is a reference model developed by the Supply Chain Council. In this model, reliability, responsiveness, and agility are the indices of customer satisfaction, and cost and asset are the indices of financial performance. Therefore, in this research we adopt the improvement of return on asset as a financial index that indicates whether or not the profit brought in by a company corresponds to its company size. We also adopt a reduction of lead time and an increase of on-time delivery as indices of customer satisfaction.

\subsection{Research Hypotheses}

From the perspectives of the preceding section, we can establish the following three hypotheses.

H1. The SCM interpretation will have a significant association with the SCM strategy.

H2. The SCM strategy will have a significant association with business accomplishment both directly and indirectly through the amount of organizational cooperation.

H3. The level of organizational cooperation and capability of business accomplishment will have a significant association with the SCM performance.

A multivariate statistical technique, namely, structural equation modelling was used to empirically test the proposed hypotheses.

\section{METHODOLOGY}

To evaluate the relationship between the SCM implementation method and its performance, we tested our hypothesis using the data answered by 23 manufacturing and logistics companies in Japan. For the analysis, we used two methods: structural equation modelling, and factor analysis. In this section, we report how we collected the data and motivated the use of these methods.

\subsection{Data Collection}

We created a questionnaire sheet that inquired about the companies' SCM implementation methods, and sent them to 77 Japanese companies that had already implemented SCM, and also used 23 new samples. A breakdown of the collected data is shown in Table 2. The respondents were required to be SCM managers or executives. The questionnaire sheets were sent and answered by mail or e-mail. Target business categories of this research were manufacturers and distributors. The manufacturers included electrical equipment manufacturers, machine manufacturers, automobile manufacturers, and food manufactures. In this research, implementation of SCM simply meant that the respondents perceived that they had implemented SCM. This is because, as mentioned in the preceding section, the definition of SCM is subject to interpretation. This led companies to differ in their opinions of what SCM implementation meant and the methods used to do so. The measures of this study were the subcategories of the proposal causal model summarized in Table 1. They were measured using multiple indicators on 5-point Likert scale (e.g., strongly disagree-1, and strongly agree-5). 
In order to measure the performance of the SCM implementation method, techniques using exacting financial data were employed. However, it is necessary to consider that seeing the effects of SMC implementation is a long-term process. It was difficult to measure the effect of SCM implementation in the financial transition. Therefore, in this

Table 2 Profile of sample companies

\begin{tabular}{llc}
\hline & Type of industry & $\begin{array}{c}\text { Number of } \\
\text { samples }\end{array}$ \\
\hline \multirow{3}{*}{ Manufacturer } & Electrical equipment & 6 \\
& Machines & 5 \\
& Food & 7 \\
& Apparel & 2 \\
\hline \multirow{2}{*}{ Distributor } & 3PL & 1 \\
& Logistics subsidiary & 1 \\
\hline Others & & 1 \\
\hline
\end{tabular}

study we investigated the effects of SCM implementation by asking how much they assumed the SMC performance was connected with SCM implementation. According to the collected data shown in Table 3, it can be shown that the mean of all the subcategories exceeded a value of 3.0. This result indicates that the SCM has already been implemented. The standard deviation (S.D) shows that the dispersion of the existence of joint goal setting is large. This indicates that there were large differences between the companies that tackled goal setting actively and the companies which did not. The investigation of variation in time was conducted because we received both preparatory and main survey responses from twelve firms.

\subsection{Data Analysis}

Before the main survey was conducted, a preparatory survey was carried out in 2010. Twelve firms answered both surveys. Table 4 shows the transition of the means for SC performance. It can be seen that three firms improved their SCM performance, three firms maintained their SCM performance, and six firms decreased their SCM performance and deteriorated the index of ability of inventory management, the reduction of lead time, and the amount of on-time delivery. We acknowledge that the Tohoku-Pacific Ocean Earthquake and Thailand Floods of 2011 likely had an adverse effect on SCM performance. As Christopher et al. (2004) and Tang (2006) said, it is necessary for supply chains to be resilient.

\subsubsection{Structural equation modelling}

We applied the questionnaire data to the causal model using structural equation modelling. Our model was not well identified. We hypothesize that this resulted from an insufficient quantity of data. Therefore, we used factor analysis to identify the factors potentially involved in the obtained results. We also applied the results of factor analysis to regression analysis in order to investigate the relationship between the factors and subcategories of SCM performance.

\subsubsection{Factor Analysis}

In order to verify the factors potentially responsible for the data results, we applied factor analysis using Varimax rotation. In the factor analysis, we used a measure factor method applying the 15 items indicated in Table 1, excluding the three subcategories of SCM performance. After the factor analysis, there were five factors whose eigenvalues exceeded one, and their cumulative percentage of variance was $68 \%$. Table 5 depicts the Varimax rotated factor loadings.

Table 3 Results of questionnaire sheet

\begin{tabular}{|c|c|c|c|}
\hline Factor & Item & Mean & S.D \\
\hline \multirow{3}{*}{$\begin{array}{l}\text { The level of } \\
\text { SCM potential }\end{array}$} & $\begin{array}{l}\text { Accuracy of the interpretation of } \\
\text { the definition of SCM }\end{array}$ & 4.13 & 0.81 \\
\hline & $\begin{array}{l}\text { Expectation toward the } \\
\text { introduction of SCM }\end{array}$ & 4.13 & 0.87 \\
\hline & Aggressiveness of reforming firms & 3.43 & 1.04 \\
\hline \multirow{3}{*}{$\begin{array}{l}\text { The level of } \\
\text { SCM strategy }\end{array}$} & $\begin{array}{l}\text { Practical use of information } \\
\text { technology }\end{array}$ & 4.13 & 0.63 \\
\hline & $\begin{array}{l}\text { Existence of proper efficiency } \\
\text { rating system }\end{array}$ & 3.83 & 0.58 \\
\hline & $\begin{array}{l}\text { Practical use of appropriate } \\
\text { outsourcing }\end{array}$ & 3.26 & 1.01 \\
\hline \multirow{6}{*}{$\begin{array}{l}\text { The level of } \\
\text { organizational } \\
\text { cooperation }\end{array}$} & Existence of joint goal setting & 3.26 & 1.32 \\
\hline & Practical information sharing & 3.87 & 0.55 \\
\hline & $\begin{array}{l}\text { Width of related companies in a } \\
\text { supply chain }\end{array}$ & 3.61 & 0.94 \\
\hline & $\begin{array}{l}\text { Existence of proper logistics } \\
\text { network }\end{array}$ & 3.48 & 1.08 \\
\hline & Existence of simple SCM structure & 2.91 & 0.90 \\
\hline & $\begin{array}{l}\text { Existence of appropriate } \\
\text { commission }\end{array}$ & 2.96 & 0.93 \\
\hline \multirow{6}{*}{$\begin{array}{l}\text { Capability of } \\
\text { business } \\
\text { accomplish- } \\
\text { ment }\end{array}$} & $\begin{array}{l}\text { Capability of inventory } \\
\text { management }\end{array}$ & 3.09 & 0.90 \\
\hline & Flexibility to customer demand & 3.61 & 0.78 \\
\hline & Practice of Just-in-time method & 3.52 & 1.04 \\
\hline & Quality of product & 4.13 & 0.63 \\
\hline & Reduction of lead time & 4.09 & 0.79 \\
\hline & Increase of on-time delivery & 4.09 & 0.79 \\
\hline \multirow{3}{*}{$\begin{array}{l}\text { SCM } \\
\text { Performance }\end{array}$} & Improvement of return on asset & 3.39 & 1.08 \\
\hline & $\begin{array}{l}\text { Increasing of customer } \\
\text { satisfaction level }\end{array}$ & 3.35 & 0.98 \\
\hline & Increasing of repeat ratio & 3.04 & 0.88 \\
\hline
\end{tabular}

According to the results of the factor analysis, the factor loadings of simple SCM structure, joint goal setting, and aggressiveness of reforming firms were the high items of factor 1. Therefore, factor 1 was determined to correspond to the capability of construction for SCM. Amongst the items of factor 2, the factor loadings of the subcategories of the SCM strategy were high, so factor 2 was determined to correspond to SCM strategy. Amongst the items of factor 3, the factor loadings of the subcategories of business accomplishment were high, so factor 3 was determined to correspond to business accomplishment. Against the items of factor 4, the factor loadings of the subcategories of organizational cooperation were high, so factor 4 was determined to correspond to organizational cooperation. The factors obtained through factor analysis were consistent with those of the proposal causal 
model. We refer to the corresponding factors as the strength of the capability of business accomplishment.

The named factors are indicated in Table 6. Compared with the factors in the proposal causal model, these factors gained by factor analysis are close to them. We refer to the corresponding factors as measures of capability for SMC construction, SCM strategy, business accomplishment, and organizational cooperation.

Table 4 Transition of the means for SC performance

\begin{tabular}{cc}
\hline Preparatory Survey & Main Survey \\
\hline $3.2(n=3)$ & $4.0(n=3)$ \\
$4.3(n=3)$ & $4.3(n=3)$ \\
$4.4(n=6)$ & $3.7(n=6)$ \\
\hline
\end{tabular}

\subsubsection{Applying the results of factor analysis to regression analysis}

To investigate the relationship between the factors we obtained through factor analysis and the items of SCM performance, we applied the results of factor analysis to regression analysis.

Table 5 Varimax rotated factor loadings

\begin{tabular}{lllll}
\hline \multicolumn{1}{c}{ Item } & $\begin{array}{c}\text { Factor } \\
\mathbf{1}\end{array}$ & $\begin{array}{c}\text { Factor } \\
\mathbf{2}\end{array}$ & $\begin{array}{c}\text { Factor } \\
\mathbf{3}\end{array}$ & $\begin{array}{c}\text { Factor } \\
\mathbf{4}\end{array}$ \\
\hline $\begin{array}{l}\text { Existence of simple SCM } \\
\text { structure }\end{array}$ & 0.72 & -0.17 & 0.04 & 0.02 \\
$\begin{array}{l}\text { Expectation toward the } \\
\text { introduction of SCM }\end{array}$ & 0.58 & 0.27 & 0.12 & 0.40 \\
$\begin{array}{l}\text { Existence of joint goal } \\
\text { setting }\end{array}$ & 0.81 & 0.11 & -0.09 & 0.40 \\
$\begin{array}{l}\text { Accuracy of the } \\
\text { interpretation of the } \\
\text { definition of SCM }\end{array}$ & 0.63 & 0.37 & 0.20 & -0.13 \\
$\begin{array}{l}\text { Aggressiveness of } \\
\text { reforming firms }\end{array}$ & 0.79 & 0.26 & 0.05 & 0.17 \\
$\begin{array}{l}\text { Practical use of } \\
\text { information technology }\end{array}$ & 0.14 & 0.64 & 0.04 & 0.57 \\
$\begin{array}{l}\text { Practice of Just-in-time } \\
\text { method }\end{array}$ & 0.35 & 0.54 & 0.22 & 0.34 \\
$\begin{array}{l}\text { Existence of proper } \\
\text { efficiency rating system }\end{array}$ & 0.10 & 0.58 & -0.19 & 0.14 \\
$\begin{array}{l}\text { Quality of product } \\
\begin{array}{l}\text { Width of related } \\
\text { companies in a supply } \\
\text { chain }\end{array}\end{array}$ & 0.03 & 0.99 & 0.09 & -0.13 \\
$\begin{array}{l}\text { Capability of inventory } \\
\text { management }\end{array}$ & 0.50 & -0.01 & 0.63 & 0.13 \\
$\begin{array}{l}\text { Flexibility to customer } \\
\text { demand } \\
\text { Increase of on-time } \\
\text { delivery }\end{array}$ & 0.15 & 0.01 & 0.99 & -0.04 \\
$\begin{array}{l}\text { Existence of appropriate } \\
\text { commission }\end{array}$ & 0.56 & -0.20 & 0.30 & 0.56 \\
$\begin{array}{l}\text { Practical information } \\
\text { sharing }\end{array}$ & -0.03 & 0.16 & 0.13 & 0.95 \\
\hline $\begin{array}{l}\text { Eigen value } \\
\text { Cumulative \% of } \\
\text { variance }\end{array}$ & 3.28 & 2.48 & 2.41 & 1.98 \\
\hline & 0.22 & 0.38 & 0.54 & 0.68 \\
\hline
\end{tabular}

In the regression analysis, three items included in the performance factor of the proposed model were used as objective variables. Factor scores were used as explanatory variables. The results after using the best subset are depicted in Table 7.

For the case in which ROA was used as an objective variable, the value of adjusted $R^{2}\left(R^{* 2}\right)$ is not desirable $(0.57)$. However, P-values of the capability of construction for SCM that were selected as explanatory variables were significant in $5 \%$ of the cases. For the case in which increasing customer satisfaction was used as an objective variable, $\mathrm{R}^{* 2}$ is not desirable (0.57). However, P-values of the capability of construction for SCM and the capability of business accomplishment that were selected as explanatory variables were significant in $5 \%$ of the cases. In case in which the increase of repeat ratio was used as an objective variable, the $\mathrm{R}^{* 2}$ is not so desirable (0.53). However, P-values of the capability of construction for SCM and the capability of business accomplishment that were selected as explanatory variables were significant in $5 \%$ of the cases. These results indicate that the improvement of the factor named as practice of business-critical matter that includes the capability of inventory management, flexibility to customer demand, etc. is connected to SCM performance.

Table 6 Named factors

\begin{tabular}{cl}
\hline & \multicolumn{1}{c}{ Factor name } \\
\hline Factor 1 & Capability of construction for SCM \\
Factor 2 & Level of SCM strategy \\
Factor 3 & Capability of business accomplishment \\
Factor 4 & Level of organizational cooperation \\
\hline
\end{tabular}

Table 7 Result of regression analysis

\begin{tabular}{|llll|}
\hline & $\square$ & $t$ & $p$ \\
\hline Factors for improvement of ROA & & & \\
Capability of construction for SCM & 0.70 & 5.01 & 0.00 \\
Level of SCM strategy & 0.25 & 1.77 & 0.09 \\
Capability of business accomplishment & 0.26 & 1.87 & 0.08 \\
Level of organizational cooperation & 0.20 & 1.40 & 0.18 \\
& & & \\
$R^{2}=0.65, R^{* 2}=0.57$ & & & \\
\hline Factors for Increasing of customer satisfaction level & & \\
Capability of construction for SCM & 0.62 & 4.41 & 0.00 \\
Level of SCM strategy & 0.27 & 1.93 & 0.07 \\
Capability of business accomplishment & 0.40 & 2.85 & 0.01 \\
Level of organizational cooperation & 0.19 & 1.35 & 0.19 \\
& & & \\
$\mathrm{R}^{2}=0.65, \mathrm{R}^{\star 2}=0.57$ & & & \\
\hline Factors for Increasing of repeat ratio & & & \\
Capability of construction for SCM & 0.63 & 4.27 & 0.00 \\
Level of SCM strategy & 0.30 & 2.03 & 0.06 \\
Capability of business accomplishment & 0.34 & 2.31 & 0.03 \\
$\mathrm{R}^{2}=0.59, \mathrm{R}^{\star 2}=0.53$ & & & \\
\hline
\end{tabular}




\subsection{Discussion}

According to the results of the preceding sections, it can be concluded that the factor named as practice of businesscritical matter is connected to SCM performance. This factor includes the subcategory, capability of inventory management, which was also investigated by Arashida et al., regarding its effect on financial performance. This consistency demonstrates the effectiveness of investigating

SCM implementation as a measure of financial performance (e.g. inventory turnover and ROA) for objective variables to use questionnaire sheets that inquire as to whether the companies could improve their performance or not.

Furthermore, it revealed the undisclosed factor of the ambiguity surrounding the interpretation of the SCM definition. However, because of the limited number of observations, the relationship between this factor and SCM performance could not be investigated in this research. Further research is required to achieve this.

\section{CONCLUSION}

The purpose of this paper was to proposes a causal model of the SCM implementation method and SCM performance.

This paper provides a proposal causal model of an SCM implementation method and SCM performance by referencing several research studies. It was revealed that there are existing factors similar to our proposed causal model used in conjunction with the questionnaire survey. Their influences on SCM also revealed performance metrics. Especially, the improvement of the practice of business-critical matter factor, which includes the capability of inventory management and flexibility to customer demand, amongst other factors, is an efficient means of improving SCM performance. As a result of the analysis, we revealed that there is an undisclosed factor related to the ambiguous interpretation of the definition of SCM. Further research is required to collect a sufficient quantity of data to re-analyse and re-investigate the relationship between the SCM implementation method and SCM performance.

Moreover, many Japanese firms were affected by Tohoku-Pacific Ocean Earthquake and Thailand Floods, thereby decreasing the SCM performance. This highlights the importance of creating resilient supply chain networks.

\section{REFERENCE}

Arashida, K., Enkawa, T., Hamasaki, A. and Suzuki, S. (2004). Developing the SCM logistics scorecard and analyzing its relation to the managerial performance (in Japanese). Journal of Japan Industrial Management Association, 55(2), pp. 95-103.
Bowersox, D. J., Closs, D. J., Cooper, M. B. (2004). Supply Chain Logistics Management (in Japanese). Asakura, Tokyo, Japan.

Browning, B. and White A. (2000). Collaborative Transportation Management. Logility, Inc. White Paper.

Cagliano, R., Caniata, F., Spina G. (2004). Lean, Agile and Traditional Supply: How Do They Impact Manufacturing Performance?. Journal of Purchasing and Supply Management, 10(4-5), pp. 151-164.

Christopher, M. and Peck, H.,(2004). Building the resilient supply chain. International Journal of Logistics Management, 15(2), pp. 1-13.

Goldratt, E. M., Cox, J., (2001). The Goal: A Process of Ongoing Improvement (in Japanese). Diamond, Tokyo, Japan.

Goldratt, E. M., Schragenheim,E., Ptak,C. A., (2002), Necessary but Not Sufficient: A Theory of Constraints (in Japanese), Diamond, Tokyo, Japan.

Goldratt, E. M., Eshkoli, I., Brownleer, J., (2009), Isn't It Obvious? (in Japanese). Diamond, Japan.

Kim, S. W. (2009). An investigation on the direct and indirect effect of supply chain integration on firm performance. The International Journal of Production Economics, 119(2), pp. 328-346.

Mentzer, J. T., DeWitt, W., Keebler, J. S., Min, S., Nix, N. W., Smith, C. D., Zacharia, Z. G. (2001). Defining Supply Chain Management. Journal of Business Logistics, 22(2), pp. 1-25.

Kijung, S., (2006). A Study on Performance Measurement Index of Supply Chain Management (in Japanese). Journal of Japan Society for Production Management, 13(1), pp. 137-142.

Petersen, K. J., Ragatz, G. L., Monczka, R. M., (2005). An Examination of Collaborative Planning Effectiveness and Supply Chain Performance. The Journal of Supply Chain Management, 41(2), pp. 823-839.

Sukwadi, R., Wee, H-M, Yang, C-C, (2013). Supply chain Performance Based on the Lean-Agile Operations and SupplierFirm Partnership: An Empirical Study on the Garment Industry in Indonesia. Journal of Small Business Management, 51(2), pp. 297-311.

Suzuki S., Kitamura S., Enkawa, T., (2009). The Influence of Market Uncertainty on SCM Competencies and Managerial Performance (in Japanese). Journal of Japan Industrial Management Association, 60(2), pp. 70-76.

Tang, C. S., (2006). Robust strategies for mitigating supply chain disruptions. International Journal of Logistics: Research and Applications, 9(1), pp. 33-45.

Yeung, A. C. L. (2008). Strategic Supply Management, Quality Initiative, and Organizational Performance. Journal of Operation Management, 26(4), pp. 490-502

Yasutaka Kainuma is associate professor of Operations Management in Department of Management Systems Engineering, Faculty of System Design, Tokyo Metropolitan University, Japan. He received a Ph.D. from School of Science and Technology, Meiji University. His research interests include supply chain management, closed-loop supply chain, sustainable operations and remanufacturing. He won the best paper award of the 21th ICPR (2011) and the outstanding paper award of the $14^{\text {th }}$ APIEMS Conference (2013). 